\title{
The Objectivity of Foreign Crisis Reports in the American Press. News about Finland in 1941
}

By

Seikko Eskola

University of Tampere

From the spring of 1941 to the Pearl Harbour catastrophe the following December, Finland was in a situation which, viewed from the perspective of the United States, aroused both interest and contradictory emotions. There were exceptionally strong feelings of sympathy for that small country, which was admired as the hero of the recent Winter War. The press had squandered expensive front-page space in covering this conflict. Sympathy for Finland was also reinforced by the reputation the country had acquired in the early thirties as the only nation in Europe to honestly repay its debts.

Now, however, Finland had been drawn into Hitler's wake and had become involved in the hostilities following his attack on the Soviet Union on 21st June. This created a lot of moral problems and provided a subject for deliberation and debate. In addition to that, the war was given an increasing amount of press coverage, especially as the theatres of operations shifted. And at the same time, the United States itself drifted closer and closer to Britain and into an increasingly sharp confrontation with Hitler's Reich.

Finland also became involved in the dynamics of American internal politics. The struggle between isolationism and internationalism-interventionism was still undecided. The isolationists had, however, been pushed into a defensive position and were struggling actively. Little Finland also fitted admirably into their arsenal of ideological arguments against President Roosevelt's increasingly favourable policy towards Stalin's Soviet Union.

Research into press history has generally been focused on newspapers and magazines as a political force and as indicators of attitudes. Virtually without exception, the subject of research has 
consisted of leaders and other articles expressing editorial stances. By contrast, very little attention has been devoted to the factual information mediated by the papers, to the news reports and their correctness. And even when these latter features have been researched, they have been examined primarily as attitude indicators. But the principal aspect has been completely ignored: the extent to which they have given a correct and truthful picture of events and phenomena.

This is methodologically a much more difficult task. And it seems to have daunted historical researchers. But it is also obvious that by following just this path press history could find an area of common interest with journalistic research. It is only when we examine historical material that we can experience both the picture conveyed by the press in its news reports and what actually happened and was reflected in the news. Only a comparison of these two things can create the preconditions for studying the objectivity of news mediation. After all, what is objectivity if not correspondence between the picture the information media have given of a particular matter and the reality of that same matter? Likewise, objective news mediation must be recognized as an ideal towards which the entire democratic press must aspire. Thus research in this area is extremely important.

I shall now proceed to outline the results of one of my studies, which examines the correctness of news reports about Finland in the American press in 1941.1 The record of events as established by historical research was compared with the image projected by certain American newspapers. The work of Professor Jørgen Westerståhl of Sweden has been extremely useful in establishing a working definition of "objectivity." Professor Westerståhl has set up the following model:

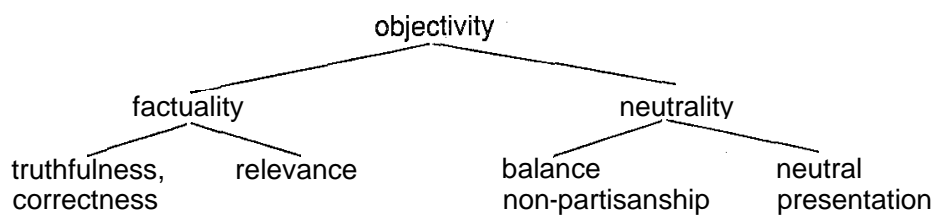

Here, truthfulness means the degree to which individual news items correspond to the reality of what actually occurred. Relevance means that significant and important events are dealt with in the sequence they occur. The other sub-factor in neutrality, balance, means that news present the views of all parties to a conflict. 
The only way to check the truthfulness of data is to examine individual news items. This was done by comparing the data reported with the actual events in each individual case and by trying to discover any errors in them. In order to examine the degree of balance of the news supplied, a quantitative exploration of its origins was carried out and the perspective from which events were viewed was examined. The relevance of news mediation was studied by examining how the press had described the most important event complexes. Relevance is a property of news totalities rather than of individual news items.

In the study, two prestige interventionist papers were examined: the New York Times (NYT) and the Christian Science Monitor (CSM). The isolationists were represented by Robert McCormick's Chicago Tribune (CT) and William Randolph Hearst's Journal-American (JM). The largest and most important weekly newsmagazines and a number of opinion journals were also included. The total assortment had to rtmain small, since our method presupposed that each individual news item be compared with the actual sequence of events. The study also encompassed an examination of the attitude to Finland taken in the papers' editorials and other opinion columns. However, in this presentation we have confined ourselves to news items.

By even the strictest criteria, the volume of interest devoted to Finland can be regarded as considerable. In fact, in the course of the seven months involved, the four newspapers carried nearly a thousand articles dealing with Finland. The total comes to nearly fifteen hundred if indirect references to Finland are also included.

Table 1. News items about Finland.

\begin{tabular}{ccc} 
Paper & Number & $\%$ \\
CSM $\ldots \ldots \ldots \ldots$ & 127 & 13,6 \\
CT $\ldots \ldots \ldots \ldots \ldots$ & 238 & 25.4 \\
J-A $\ldots \ldots \ldots \ldots$ & 169 & 18.0 \\
NYT $\ldots \ldots \ldots \cdots$ & 403 & 43.0 \\
\cline { 2 - 3 } Total $\ldots \ldots \ldots \ldots$ & 937 & 100.0
\end{tabular}

Table 2. Average no. of news items about Finland per issue, 21.6-7.12 1941.

$\begin{array}{cc}\text { Paper } & \text { Number } \\ \text { CSM } \ldots \ldots \ldots \ldots \ldots & 0.9 \\ \text { CT } \ldots \ldots \ldots \ldots \ldots & 1.4 \\ \text { J-A } \ldots \ldots \ldots \ldots \ldots & 1.0 \\ \text { NYT } \ldots \ldots \ldots \ldots & 2.4\end{array}$


Finland was a regular feature in the New York Times. In only one issue a-week, on average, did this paper fail to carry a story about Finland. It was also a fairly regular feature in the Chicago Tribune, being absent from only every third issue on average. The isolationist papers had a front-page story about Finland in every fourth issue. There was one in the New York Times about every fifth issue, and in the Christian Science Monitor about every eight.

Table 3. Front-page stories about Finland, 21.6-7.12 1941.

$\begin{array}{lllll} & \text { CSM } & \text { CT } & \text { J-A } & \text { NYT } \\ \text { No. } \ldots \ldots \ldots \ldots \ldots \ldots \ldots \ldots \ldots & 18 & 40 & 41 & 35 \\ \text { No. per issue } \ldots \ldots \ldots \ldots \ldots \ldots \ldots & 0.12 & 0.24 & 0.24 & 0.2\end{array}$

Finland was mentioned in the New York Times more often than Italy or all the eastern European countries together and to the same extent as South America and Scandinavia. Let us have another look at how the articles dealing with Finland can be broken down into different kinds of journalistic items:

Table 4. Composition of material dealing with Finland.

$\begin{array}{lllll}\text { Type of story } & \text { CSM } & \text { CT } & \text { J-A } & \text { NYT }\end{array}$

\begin{tabular}{|c|c|c|c|c|}
\hline news item & 58 & 209 & 136 & 327 \\
\hline front-page review $\ldots \ldots \ldots \ldots$, & 31 & - & _ & 42 \\
\hline leader. $\ldots \ldots \ldots \ldots \ldots \ldots \ldots$ & 6 & 9 & 5 & 9 \\
\hline column $\ldots \ldots \ldots \ldots \ldots \ldots$ & 9 & - & 10 & 3 \\
\hline comment, editorial article. ..... & 3 & 2 & 3 & 6 \\
\hline signed article $\ldots \ldots \ldots \ldots \ldots$ & 18 & 4 & 3 & 6 \\
\hline cartoon $\ldots \ldots \ldots \ldots \ldots \ldots \ldots$ & 1 & 2 & 1 & 2 \\
\hline maps $($ separate $) \ldots \ldots \ldots \ldots \ldots$ & - & 3 & 8 & - \\
\hline pictures (separate) $\ldots \ldots \ldots \ldots$ & _ & 4 & 1 & 1 \\
\hline despatches $\ldots \ldots \ldots$. & 1 & 5 & 7 & 7 \\
\hline Total $\ldots \ldots \ldots \ldots \ldots \ldots$ & 127 & 238 & 169 & 403 \\
\hline
\end{tabular}

Thus the bulk of the material, over $90 \%$, consisted of news. This shows what a narrow part of a paper's material is covered by ordinary press-historical research. Finland was also featured in editorials and columns on several occasions, even in cartoons, to which the entry threshold was quantitatively the highest.

Our next task is to answer the question of whether the news mediation was impartial in the sense that data were received from both sides of the Fenno-Soviet conflict on a relatively even basis and, secondly, whether these news items were correct when compared with extra-media data. Only by examining individual news items and their statistical totality could these two matters be 
ascertained. After that, we shall consider the question of the news items' relevance, which presuppose the coverage or non-coverage of larger event totalities and impartial use of language.

The American papers had quite good facilities for news gathering. The New York Times, the Chicago Tribune and the Associated Press news agency all had their own correspondents in Helsinki. These were capable of speaking either one or the other (or both) of the two official languages of the country, Finnish and Swedish, and were familiar with local conditions. The Chicago Tribune's correspondent was the famous Donald Day, who had spent the entire period between the wars in the Baltic countries and reported on conditions in eastern Europe. As can be seen from our comparison of the newspapers' news volumes, they made efficient use of their correspondents' material.

If we compare the articles published by the papers with the texts dictated by the correspondents themselves and given to the Finnish censorship authorities (after which they were deposited in the State Archives in Helsinki), we can establish that in choosing their material the editorial sections did not use political selection principles any different from those of the correspondents.

The American papers obtained their material about Finland from very many different cities. This is shown by the following table, which contains a breakdown by city of origin of material concerning Finland published in the New York Times during the period of our study.

Table 5. Breakdown of news reports (= despatches) by source area and theme. Absolute and relative figures.

The news items are divided into three categories according to the themes they deal with. The first of these categories consists of military matters and events on the front (Mil.) ; the second consists of Finnish internal policy and internal civilian affairs (Int.) and the third with foreign policy and external relations (For.).

\begin{tabular}{|c|c|c|c|c|}
\hline Absolute & & New & Times & \\
\hline City & Mil. & Int. & For. & Total \\
\hline$\ldots \ldots \ldots \ldots \ldots \ldots$ & 168 & 16 & 48 & 232 \\
\hline Stockholm $\ldots \ldots \ldots \ldots \ldots \ldots$ & 26 & 6 & 54 & 86 \\
\hline 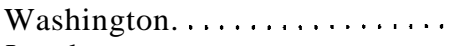 & 3 & 3 & 47 & 53 \\
\hline London $\ldots \ldots \ldots \ldots \ldots \ldots \ldots$ & 6 & 1 & 29 & 36 \\
\hline$\ldots \ldots \ldots \ldots \ldots$ & 25 & - & 17 & 42 \\
\hline$\ldots \ldots \ldots \ldots \ldots$ & 16 & 2 & 12 & 30 \\
\hline Berne .... & 23 & - & 2 & 25 \\
\hline 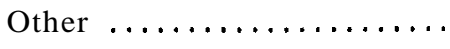 & 3 & - & 10 & 13 \\
\hline Total ... & 270 & 28 & 219 & 517 \\
\hline
\end{tabular}




\begin{tabular}{|c|c|c|c|c|}
\hline Kelamve (\%) & Mil. & Int. & For. & Total \\
\hline Helsinki $\ldots \ldots \ldots \ldots \ldots \ldots$ & 32.6 & 3.1 & 9.3 & 45.0 \\
\hline Stockholm $\ldots \ldots \ldots \ldots \ldots$ & 5.0 & 1.2 & 10.4 & 16.6 \\
\hline Washington. ............... & 0.6 & 0.6 & 9.1 & 10.3 \\
\hline London $\ldots \ldots \ldots \ldots \ldots \ldots \ldots$ & 1.2 & 0.1 & 5.6 & 6.9 \\
\hline Berlin $\ldots \ldots \ldots \ldots \ldots \ldots \ldots$ & 4.8 & - & 3.3 & 8.1 \\
\hline Moscow $\ldots \ldots \ldots \ldots \ldots \ldots$ & 3.1 & 0.4 & 2.3 & 5.8 \\
\hline Berne $\ldots \ldots \ldots \ldots \ldots \ldots \ldots$ & 4.4 & - & 0.4 & 4.8 \\
\hline Other $\ldots \ldots \ldots \ldots \ldots \ldots \ldots$ & 0.6 & - & 1.9 & 2.5 \\
\hline & 2.3 & 5.4 & 42.3 & 00.0 \\
\hline
\end{tabular}

Helsinki was indisputably the most important source of news reports appearing in the NYT. There, the news was affected by the Finnish censorship authorities, who tried to prevent news unfavourable to Finland from becoming public. But half the news reports originated outside Finland and were thus unaffected by the censors. A particularly important source of news in those days was Stockholm, which was then a centre for espionage, speculation and various kinds of international contacts. Through Stockholm the American papers received plenty of information which had come across the Finnish border and which also contained material considered negative from the Finnish point of view.

Although more emphasis was laid on reports from Finland, some reports were also received from Moscow. There, however, the NYT's correspondent C. I. Sulzberger had to rely on Russian material only and therefore his news reports and comments were often made from a Russian perspective. A further important source in our table is Berne, where the NYT's correspondents used foreign material to prepare their own reports, which they then furthered to New York. This material was strongly Russian-influenced and the Russian point of view in it was quite obvious. Material critical of Finland also came from London. Thus the supply of news about Finland was relatively balanced, although the bias was clearly in Finland's favour.

It is interesting to note how much news about Finland reached the NYT from Washington. Credit for this is largely due to Finland's energetic ambassador Hjalmar J. Procopé and the Finnish Embassy. In their contacts with the management of the NUT, both Ambassador Procopé and his staff were eminently successful in having Finland's point of view projected in a variety of awkward questions. The Soviet Embassy does not seem to have been so successful in this respect. 
In the newspapers we examined, news items about the FennoSoviet conflict usually looked at the matter from the Finnish point of view, but in the NYT and the CSM, in particular, the Russian view was also presented. In the isolationist papers, however, the latter feature was rarer. By contrast, during Finland's foreign policy crises with Britain and the United States, the supply of news was, generally speaking, quite balanced. Both points of view were presented. It must, however, be pointed out that when diplomatic relations between Finland and Britain were severed in late July, the matter was reported in the American press mainly from the British point of view.

A detailed comparison of these news items with what we now know to have been happening then shows that the American papers' reports contained quite substantial errors and considerable exaggerations. Incorrect data and erroneous speculations cropped u p right through the press. But it must be pointed out that in the news totalities, in the overall pattern of reporting, the erroneous parts represented only a relatively small part of the total.

In about one thousand news items about Finland examined by us, the reports were found to be downright erroneous in only some 50 cases, a rate of $5 \%$. One interesting aspect of this is the fact that most of the erroneous news items were in the New Yak Times, in other words, in the paper which newspapermen then based in Washington regarded as the most reliable from the point of view of news reporting when they were making their assessments. There were fewer errors in the Chicago Times and the Journal-American, which they regarded as unreliable. Of course, this stems to an important degree from the fact that the NYT carried such a great deal more information than the other papers.

The incorrect news items stemmed from only a few sources. Where the New Yok Times is concerned, it could be established that the data sent in by the paper's Stockholm and Berne correspondents often contained errors, even gross ones. Indeed, their information c an be considered downright unreliable. On the other hand, it must be pointed out that the material originating in Stockholm, in particular, also contained a lot of very significant information, which could not be obtained from other sources. There were also striking 'errors in some of the news despatches from Moscow, which were published in both the Chicago Tribune and the Nerw Yok Times. Where the truthfulness component was concerned, there was more to criticize in the NYT than in the other papers. However, where 
the balance and diversity of the news supplied was concerned, not to mention the volume of information, the situation was the direct opposite.

It is not possible in this connection to go into a detailed description of how the American press handled the many events of the dramatic early stage of Finland's so-called Continuation War. We can only point out that for a couple of weeks prior to Hitler's attack, Finland. appeared in the American press as a kind of storm signal in the international weather forecast. This was due to the arrival of German forces in northern Finland. After that, the papers devoted considerable attention to the events of the chaotic days during which Finland became embroiled in the war.

The severance of relations with Britain in late July was reported from a variety of angles, as were the armistice dispute in early September and the United States' efforts to pressure Finland into making a separate peace with the Soviet Union in November. Throughout the entire period, most attention was given to military reports from the front, but Finland's internal affairs were also covered.

In this connection, we can only note that on the whole this news reporting was quite relevant, because the most important sequences of events were dealt with and were generally looked at from the viewpoints of the various parties involved.

The other component of neutrality is neutral presentation. This can he said to have existed in relation to most of the reports about Finland examined in our study. What could be construed as direct criticism of either Finland or the Soviet Union appeared in the news comparatively seldom. However, there were quite many breaches of neutrality, to Finland's detriment, in the news reaching the New York Times from Stockholm. By contrast, all of Donald Day's information in the Chicago Tribune was openly sympathetic to Finland, not only in its news selection, but also often in its mode of expression. Nor was there anything to balance this aspect in the paper. The paper can be criticized more on the neutrality count than in relation to the factuality of the news it carried.

One result of the study is that it is not possible to point to anything like the same difference in objectivity between the prestige papers NYT and CSM, on the one hand, and the journalistically much criticized main Hearst paper and Robert McCormick's Chicago Tribune, on the other, which American correspondents in Washington had commented on in 1936. In that year, they had 
placed the former two among the three most reliable newspapers, while the latter two had been named the most unreliable among the entire American press!

Finally there is the question of whether the American papers were objective. Our research indicated that in these four subfactors of objectivity it was not a matter of "either - or" alternatives. Rather, it was a matter of differences in degree. The overall picture of the American press which emerges in this individual case is as follows: the news material it presented met the general criteria of objectivity comparatively well. Of course transgressions - and indeed even serious ones - against truthfulness and, above all, against impartiality, can be pointed out in relation to individual events and publications. But we cannot say whether it was objective in dealing with other crises or compared with other countries' presses in writing about comparable cases elsewhere. This would require numerous comparable studies as background material, and no such studies have been produced.

To conclude, we could still mention a couple of data to which the editorial staffs at the newspapers did not attach the importance they should have warranted. As early as April 1941, the Chicago Tribune's Helsinki correspondent Donald Day had reported that Germans in Finland and Sweden were whispering about an imminent attack on the Soviet Union and that the German GHQ's plans were nearly ready. If the editorial office at the Chicago Tribune had attached more importance to these reports, they would have been among the most important revelations in the history of journalism. But the management at the Tribune in the spring of 1941 took a more or less sceptical attitude to the reports received from their correspondent in Helsinki. More credence was attached to the reports of one of Colonel McGormick's close friends, a military man who had visited the Soviet Union early that year and obtained a good picture of its military strength.

Another interesting and similar case was a news item carried by W. R. Hearst's Journal-American in the beginning of September. This concerned the question of disengaging Finland from the war, a question which attracted considerable attention in the press, the American foreign affairs leadership having made several attempts to get Finland out of the hostilities. The Journal-American received a news report from Washington with quite precise data about both the US Secretary of State Cordell Hull's discussion with the Finnish Ambassador and the information obtained by the US Minister in 
Helsinki from the Prime Minister of Finland. These data were much more exact than those published elsewhere, and attracted a lot of attention at the time. However, the people responsible for placing news items did not appreciate the value of this particular one. It was given little space, in a rather bad location, although it contained data which nobody else had been able to get hold of, and about a matter on which a lot of the speculation had been a long way off the mark.

\section{NOTE}

1 Eskola, Seikko: Yhdysvaltain lehdisto ja Suomen Kriisi. Keväästä 1941 PearlHarboriin. Suomen Historiallinen Seura, with an English Summary: U.S. Press and Finnish Crisis, 1941." 215 p. Helsink, 1974. 